\title{
Towards Socially Just Literacy Teaching in Virtual Spaces
}

\author{
Elizabeth Isidro ${ }^{* 1}$ and Laura Teichert ${ }^{1}$
}

* Corresponding author

E-mail: elizabeth.isidro@wmich.edu

1. Dept. Special Education \& Literacy Studies, Western Michigan University, USA.

\section{Article Info}

Received: March 1, 2021

Revised: April 29, 2021

Accepted: May 24, 2021

\section{$10.46303 / j c s r .2021 .6$}

\section{How to cite}

Isidro, E. and Teichert, L. (2021). Towards Socially Just Literacy Teaching in Virtual Spaces. Journal of Curriculum Studies Research, 3(1), 21-41. https://doi.org/10.46303/jcsr.2021.6

\section{Copyright license}

This is an Open Access article distributed under the terms of the Creative Commons Attribution 4.0 International license (CC BY 4.0).

\begin{abstract}
This study inquires into preservice teachers' teaching experiences within a virtual tutoring field experience in a literacy methods course. Our work is situated against the greater institutional and social-political context of a competency-based model in education and the Covid-19 pandemic that led to a shift to online instruction. From a social justice lens, we approach the research questions: What are undergraduate preservice teachers' literacy teaching experiences in a newly-transformed-to-online literacy methods course? In what ways does a virtual tutoring field experience prepare preservice teachers towards socially just literacy teaching? By engaging in Narrative Inquiry, we unraveled preservice teachers' experiences in facilitating literacy lessons that combine print-based and multimodal instruction, while learning about the specific tensions and questions that they confronted during the process. We realized that preservice teachers' virtual teaching experiences develop towards more socially just teaching along the areas of knowledge, interpretive frames, teaching strategies, methods, skills, and advocacy and activism. We further found that this approach is a complex process characterized by the personal, contextual, and relational aspects of teaching. KEYWORDS

Virtual tutoring; social justice; curriculum studies; teacher education; online teaching; teacher stories.
\end{abstract}




\section{INTRODUCTION}

Designing teacher education curricula is a serious undertaking fraught with personal, political, and relational tensions that educators navigate (Isidro, 2019). This work is critical when considering the social inequities based on the widening gaps in education and income (Zeichner, 2011). The COVID-19 pandemic provided more evidence of social inequities as disparity in access to good teaching widened between the rich and the poor (Horrowitz, 2020). Indeed, the need for high-quality teacher preparation has never been this urgent as more higher education courses are offered in online-only formats.

Research shows that experience integrating technology with instruction prepares preservice teachers (PSTs) for a technology-driven society (Moore-Hayes, 2011; Trumble, 2016) and provides them the necessary teaching skills for future disruptions to in-person teaching and learning (Basilaia \& Kvavadze, 2020; Toquero, 2020). However, little research shows how technology use in instruction and virtual teaching aligns with what is socially just teaching, much less socially just literacy teaching. The fundamental question for us as literacy teacher educators, then, is not just "how do we prepare our PSTs for literacy teaching within virtual contexts" but "how do we prepare PSTs for socially just literacy teaching within virtual contexts?" Needless to say, our challenge in literacy teacher education has compounded as we aim to reconstruct learning experiences for PSTs that must not only build knowledge and skills but also cultivate asset-based perspectives and advocacy for inclusivity.

This paper is an inquiry into our own work as literacy teacher educators who are trying to understand socially just literacy teaching within virtual spaces. The purpose of this study was to examine PSTs' literacy teaching experiences within a virtual tutoring context through a social justice lens. Under extraordinary circumstances, our work is situated against the greater institutional and social-political context of a competency-based model in education and the Covid-19 pandemic. The research questions that guided our inquiry: What are undergraduate preservice teachers' literacy teaching experiences in a newly-transformed-to-online literacy methods course? In what ways does a virtual tutoring field experience prepare preservice teachers towards socially just literacy teaching?

\section{A TURN TO LITERATURE}

Our limited knowledge on the topic 'socially just literacy teaching in virtual spaces' prompted us to turn to available research in the field. Our search led to three separate bodies of literature which we discuss below.

\section{PSTs and Virtual Teaching Experiences}

Kennedy and Archambault (2012) reported that only 1.3\% of US teacher education programs responded to the need for virtual school field experiences (VSFE), while $13 \%$ of the programs surveyed were in the process of planning for VSFEs. Almost a decade later, there has been no available research that documents teacher education programs' inclusion of VSFEs in their 
programs. While PSTs' hold negative misconceptions about VSFEs (Compton et al., 2010), research shows PSTs benefit from VSFEs by gaining confidence in providing instruction online and other communication skills (Wilkens et al., 2014), though building rapport and community is a challenge within online spaces (Waters \& Russell, 2016; Wilkens et al., 2014).

\section{Socially Just Teaching and Literacy Instruction}

Many scholars have conducted literacy teaching research that embodies some elements of social justice. For example, the seminal work describing the need for culturally responsive curriculum and pedagogy (Au \& Jordan, 1981; Gay, 2002; Ladson-Billings, 1995; Villegas \& Lucas, 2002). Though specific use of the term 'socially just literacy teaching' is less common in research, studies have addressed the idea of social justice in relation to literacy teaching, albeit with varying emphases. For instance, we learned that examination of social justice-oriented professional development among literacy teachers and professors resulted in a better understanding of culturally relevant instruction, the place of oneself and values in the classroom, and transformative curriculum (Rogers et al., 2005). Teacher educators should also revisit PST curricula and include critical reflection, use common vocabulary across courses in the program, emphasize connection between theory and practice, and dismantle stereotypes that perpetuate structural inequalities (Aronson et al., 2020). Research shows that PSTs come to our program with little understanding of socially just teaching, but those initial conceptions may (or may not) change based on contextual factors (Lee, 2011). Yet, with exposure to students from diverse backgrounds, PSTs are apt to revisit their own assumptions about students of color and disrupt a deficit mindset towards marginalized students (Baldwin et al., 2007). The challenge lies in enacting socially just literacy teaching practices as beginning teachers navigate administrative policies, historicized beliefs about literacy instruction and assessment, limited resources, and maintaining relationships with students and other colleagues (Williamson, 2017).

\section{Socially Just Literacy Teaching in Virtual Spaces}

An emerging line of research, we found one paper that aligned with our work. Smith et al., (2020) offered guidelines that enable students to develop literacy practices for promoting respectful and trusting relationships among students and teachers in the classroom. These trustbased guidelines are: a community that is "always there" for students; letting students attend virtual meetings as themselves-- wherever they are; and, creating a safe virtual space for everyone.

While informative for our understanding of PST practices we have been seeing "in the field," there are specific limitations in the bodies of literature with regards to PSTs' virtual teaching experiences that align with socially just literacy teaching:

1. Lack of in-depth descriptions of PSTs' virtual teaching experiences;

2. Study focusing on socially just teaching experiences is based on a single-participant case study; 
3. Paper focused on socially just literacy teaching in virtual spaces but not an empirical study.

\section{Theoretical Perspectives}

Fraser's (1997) seminal work on social justice provides language for understanding this concept through the notions of redistribution, recognition, and representation. In the context of schools, redistribution refers to the equitable distribution of funds and resources to facilitate equitable access, engagement, and participation for all students (Woods, 2018). A co-fundamental is the recognition of social groups based on culture, race, gender, religion, language, sexual orientation, and ability/disability (Cochran-Smith, 2010) and, as Fraser clarified, recognizing them as equal partners and "able to participate as peers with others" in social interaction (Dahl et al., 2004, p. 377). Finally, representation refers to establishing systems that provide equitable opportunities to have multiple perspectives, consultation, and shared decision-making (Woods, 2018).

Building on Fraser's thinking, we turn to Cochran-Smith's (2010) conceptualization of social justice within the context of teaching and learning. Termed as a 'theory of practice,' she argued that socially just teaching should be a combination of the following with the overarching goal of improving student learning and their life chances:

1. Knowledge - teachers have the knowledge base but also should be able to critique it and know its limitations.

2. Interpretive frames - teachers approach their work through an inquiry stance, and believe they have the agency to influence students' life chances

3. Teaching strategies, methods, and skills - teachers know the guiding principles behind the different strategies and methods they use for specific circumstances, students, content, and communities

4. Advocacy and activism - teachers advocate with and for students, parents, colleagues, and communities

This perspective rejects a narrow definition of teaching (i.e., having subjective matter knowledge and teaching skills). Instead, it includes "how teachers think about their work and interpret what is going on in schools and classrooms; how they understand competing agendas, pose questions, and make decisions; how they form relationships with students; and how they work with colleagues, families, communities, and social groups" (Smith, 2010, p. 454).

\section{METHOD}

We utilized Narrative Inquiry methods to describe PSTs' lived experiences as they engaged in virtual tutoring with K-8 students. Narrative Inquiry involves a shaping or ordering of experiences that gives participants and researchers a way to understand experiences by organizing them into a meaningful whole (Chase, 2008; Clandinin \& Connelly, 2000). From a socially just and humanizing research perspective (Paris \& Winn, 2013), engaging in this inquiry 
is essential because it creates space for PSTs to share their personal experiences and practices about virtual teaching. The knowledge gained from this inquiry serves as a knowledge base for teacher educators to understand and promote socially just teaching in a contextualized manner (i.e., within a virtual tutoring field experience). Our inquiry was taken in four directions: inward (e.g., PSTs' internal feelings), outward (i.e., PSTs' contexts); backward and forward (i.e., past, present, and future), and opened room for questions and puzzles.

\section{Context of the Study}

This study was situated in an online literacy methods course in the elementary teacher preparation program offered by a public university in the Midwestern United States. The online course is the second of two required literacy courses, where each student is expected to complete eight hours of virtual tutoring with an assigned K-8 student. The second author taught the methods course and supervised the PSTs in tutoring, while the first author coordinated the field experiences by recruiting families and K-8 children to participate in the virtual tutoring. There were two sections of the same course, with a total of 35 PSTs enrolled.

The Fall 2020 semester was 14 weeks, which allowed PSTs four weeks of content learning before tutoring began. PSTs were paired to work with one K-8 student. To prepare PSTs for field experience, we provided videos to support PSTs' literacy pedagogy in either in-person or virtual teaching (e.g., how to use pre-assessment data to develop lesson plans). We also created online discussions to help PSTs think about literacy instruction collaboratively and how it might be adapted for an online space. PSTs were supported in this space with constant instructor feedback.

PSTs' first session consisted of implementing literacy assessments, such as an interest inventory, Qualitative Reading Inventory (QRI) word lists, and a QRI passage to assess their student's fluency and comprehension. They then planned lessons based on the literacy preassessment results.

\section{Participants}

All PSTs enrolled in the course were invited to participate and eight PSTs willingly agreed. In this paper, we center on our focal participants--Kerry, Helina, Natalie, and James-- whom we purposefully selected based on the distinct richness of their stories in relation to our theoretical framework. We also noted diversity in terms of age, race, and gender across the eight participants while remaining cognizant that their experiences and perspectives (except for Helina's) may be influenced by their White, middle-class backgrounds, which may be a prevalent phenomenon in other teacher preparation institutions.

At the time of the study, Kerry, was in her senior year, working towards an Elementary Education certification with a major in English Language Arts. Kerry is Anglo-American and a mother who described herself as a non-traditional student. The bulk of her teaching experience was teaching her own children; however, her mother was a teacher, which allowed her to 
regularly visit and volunteer in a classroom. While she had teaching experience before the course, none of it was online. Helina, the only African-American participant, was a senior and was completing an Elementary Education certificate with a major in Early Childhood Education. She, too, had no experience teaching online prior to the study. Natalie was a senior and working to complete her Elementary Education certificate with a major in Early Childhood Education. She is also of Anglo-American descent and regularly tutored middle school students. She too had no online teaching experience prior to the study. Finally, James, Anglo-American descent and the only male participant, was also in his senior year, working towards an Elementary Education degree. He entered the course with no online teaching experience but had some experience reading to elementary-aged children when he was a junior in high school.

\section{Data Sources and Analysis}

Data sources included semi-structured interviews with eight PST participants, instructor observational field notes of PSTs' virtual teaching, lesson plans, and course artifacts (e.g., final paper, discussion boards, instructor videos). Interviews were held virtually after the semester ended and lasted for approximately one hour. Interview questions focused on areas such as initial reactions to virtual tutoring, literacy lessons and instructional activities, successes and challenges, and equitable teaching practices (e.g., making content more accessible for the student).

Data analysis consisted of reading through the texts and creating margin notes to form initial codes. These codes were collapsed into categories and emerging themes. To aid with interpretation, we used both the inductive codes as well as deductive codes (i.e., based on research questions; epiphanies within stories; tenets of socially just teaching) to capture the salient points in the data (Fereday \& Muir-Cochrane, 2006). During initial coding, we engaged in coding the data independently. We then engaged in discussions to reconcile our coding differences until we achieved $100 \%$ agreement. We followed the same process when forming categories and crafting the themes for each of our participants.

\section{FINDINGS}

This section presents co-constructions of our focal participants' narratives in the virtual tutoring field experience. We tell their stories individually to highlight the differences in their journey towards socially just literacy teaching. For each individual story, we spotlighted themes within each participant's lived experiences and included quotes to capture each participant's voice in our narrative (Clandinin \& Connelly, 2000). To honor the privacy of our participants, we used pseudonyms for all individuals and schools referenced in this paper. 


\section{Stories from Virtual Tutoring}

\section{Kerry's Account}

Shifting the Focus: Personal Fears to Student's Needs. Kerry began her story recounting her fears from the onset of the pandemic when everything shifted online, and her struggle to focus on her own online learning given her other responsibilities at home. With a virtual field experience, she had wondered where to even begin and said, "I have to make videos of myself? I'm not an actress" (interview transcript, p. 1). Further listening to Kerry, we understood that these feelings could be traced back to earlier experiences:

I have a fear of being on camera. I've been mocked for how I talk when I was little. So just to be on that kind of a platform where I knew family members might hear me, it was really scary for me. (interview transcript, p.1).

Kerry also reported a low level of comfort with technology. She considered herself good with new apps but got very intimidated by them. And while she found comfort viewing [ $2^{\text {nd }}$ author's] tutorial videos in class (e.g., how to schedule a Webex meeting), questions around the use of technology remained a puzzle. This feeling extended into a discomfort for teaching online. She had wondered what literacy teaching would look like in a virtual environment, questioned her ability to keep a student on task, and thought about how to establish a connection with her student and co-tutor. She stated that the "downside of digital technology [is] that it can make people feel disconnected from one another" (final paper, p. 5). However, as she gained more experience, her initial focus on technology fears shifted to a focus on her student's needs:

[...] our student was unable to hear the audio due to technical difficulties. I quickly realized how important it is for students to have access to multiple means of representation. We wanted to be sure our student could hear and see what we were talking about, to the best of our abilities. We also observed our student struggling with some of the smaller prints presented to him on the screen and later learned that our student needed reading glasses. These experiences reinforced the need to use Universal Design for Learning guidelines in the classroom, whether it's a physical classroom, or virtual" (final paper, p. 4).

Creating Literacy Lessons for Personal Meaning-Making. Kerry was assigned to tutor a thirdgrade student, Jeremy. Some of the lessons Kerry taught included vowel digraphs and text comprehension, with a specific interest in meaning-making for the student:

[We] talked about long vowel sounds, which he knew, but he didn't know how different vowel combinations could result in that sound... we also talked about general rules on vowels, saying their names, and then we also went into creating sentences, so that he could then take those words and put them into meaning. It should have meaning rather than just being a word. So we use the word 'lie.' We had 'Jeremy likes to blank on the couch to write comic books' because Jeremy loves comic books. So, then he could pick which word fit in there, and 
then he could connect the vowel sounds with the word that he chose" (interview transcript, p. 6).

Kerry also described her comprehension lesson on predicting and inferring using the book Jumanji (Van Allsburg, 2011) based on information from the interest inventory:

I created this board because I knew he liked games, and he liked Jumanji, and it would be interactive that he could move his piece. I didn't have to move it for him, and he could just play the game, which then I did ask questions about the book. But it wasn't just, "Well, tell us who was the main character?" It was "Okay, now tell us this... (interview transcript, p. 11).

Her lesson plan demonstrated a high premium for making deep meaning from the texts, where she wrote high level open-ended questions along with asking Jeremy to evaluate how the book compared to the movie (Lesson Plan 3, p. 3).

Kerry also pointed out the importance of using games in lessons in order to build an authentic relationship with her student. She explained that instead of having Jeremy answer a list of questions, she wanted to teach to his interests and strengths. In reflection, she shared that her aim was to design creative lessons so that Jeremy would find virtual tutoring as a place for him to enjoy and be himself. According to her, she did this by connecting her lessons with the results of the interest inventory. What sounded to us as an epiphany, she shared:

We were coming up on Thanksgiving, so a lot of people might right away say, 'Oh, well, let's write a Thanksgiving book,' but we stopped to think, 'Well, what holidays do you celebrate?' and found out Jeremy does not celebrate Thanksgiving or Christmas. He celebrates Kwanzaa ... we knew right away, well, maybe in a full classroom setting, it would be appropriate to teach about Thanksgiving in the correct way. But for Jeremy, in a one-on-one setting, it wouldn't be appropriate because we're here to teach to his strengths and his interests. (interview transcript, p. 10).

Letting Go of an Agenda. As our conversation with Kerry unfolded, what became more apparent was not just a valuing of her student's interests but a decision to "let go" of the notion of a fixed lesson. Kerry explained that she had always been a planner with specific goals in mind. However, recognizing the effectiveness of flexibility with her student, she realized how important it was to work on this practice. She stated it was reassuring to know that it was okay when a lesson did not go as planned. She further noted that she just stopped thinking about the lesson agenda and instead focused on Jeremy's interests and skills. We present a specific incident below that illustrates this idea of "letting go." Kerry tried to implement a lesson based on a book that the student was supposed to read:

So we ran out of time to do the whole book, but our student was so excited about the game of asking questions. So we kind of abandoned the book idea and continued it into the next week on having him ask questions... which then led us 
into, 'Well, let's do inquiry-based lessons and let him choose a topic'. (interview transcript, p. 4).

On the other hand, Kerry said that she continued to wonder how this practice may be used in an actual classroom with a structured curriculum. She remained puzzled about deciding when and how she might be able to tweak the curriculum for her students.

Family as Part of the Classroom. As our conversation came to a close, Kerry revealed another aspect of the virtual tutoring experience that made her nervous: interacting with families. On the last day of tutoring, she virtually met with Jeremy's mother and facilitated a conference where she described Jeremy's literacy skills. She said it was a positive experience to be welcomed into Jeremy's home (virtually). She thought it was good practice to be mindful of what families may think of the things she says. She extended her thinking into her future classroom:

I think that also translates into the classroom that we want families to be a part of the classroom, and that it's not my space that they're walking into. It's their space. It's their school. It's their child's classroom. So even though it was a virtual situation where I was the guest in their home, it's also a really good lesson on how to build community with families in the classroom" (interview transcript, p. 14).

\section{Helina's Account}

When Happy is Not Ever After. Helina's initial feelings towards virtual tutoring were marked by excitement and happiness in relation to the amount of time she could save from commuting to and from school and her potential flexible schedule by being at home. She also recognized that having virtual teaching experience would strengthen her credentials for future employment. However, her optimism faded as she started feeling overwhelmed by the volume of work:

I felt in many of my classes there was more work than I would do if it was in person. And so doing all of that on top of and preparing for the virtual tutoringI've never done that before...And so really as soon as the semester started, it was work right away and then it was not fun. (interview transcript, pp. 1-2).

Helina said that she coped with the situation by creating a schedule and having an agreement with her co-tutor, Kerry, for them to alternately lead the weekly lessons with their student Jeremy.

When Challenges Come Your Way. Helina also shared more specific experiences that challenged her in virtual tutoring. For example, she remembered Jeremy having audio issues on the first day of tutoring. She and Kerry had to troubleshoot for 15 minutes and ended up using the chat and laser pointer function to continue communicating with the student. "Although we found a solution, we lost a major portion of time with the student," (final paper, p. 5). She seemed unfazed by this untoward incident and continued her story:

As far as instructional challenges, I thought that he (Jeremy) would retain the information better. So then throughout the later lessons, we tried to add more 
formative assessments and we tried to be really explicit on the main idea and then even have him repeat it multiple times so we weren't the only ones saying it. (interview transcript, p. 3).

Helina did share that she felt successful upon seeing Jeremy's progress in learning the irregularly spelled words they were focusing on in their lessons.

Getting to Know the Student. Helina shared that one way she had gotten to know Jeremy better was through the check-ins at the beginning of the session, by simply asking about his day and if there was anything special happening. According to her, this was how she and Kerry learned that Jeremy did not celebrate Halloween. In addition, she said she also asked questions at the end of the session in order to know more about his specific interests and incorporate his input into future lessons:

'What do you want to do next week or what's something that could interest you?

Do you want to write or do you want to read? Do you do want to do nonfiction next week, do you want to do fiction?' Stuff like that. And you know him, he was pretty open to sharing anything" (interview transcript, p. 8).

Helina also turned to the use of the interest inventory for text selection:

Our student was really engaged. He's just a good student overall but then it was exciting when we went back to his interest inventory and we're really intentional about doing the stuff that he said he likes. We could see him getting excited. So, for example, he likes superheroes, so we had him read about different superheroes. (interview transcript, p. 4).

A Focus on Growth. Many parts of our conversation with Helina delved into her desire to improve in several areas as a teacher. She identified her need for more creative lesson planning after recalling the large amount of time she expended online to find engaging lesson ideas. She wondered about websites and sources of texts and articles that she could offer to students:

I feel like just getting more guidance on what to do for lessons because if I didn't, then I felt like I came up with really generic things and I thought it would be cool to experiment and do really creative things that they might have never done before or something like that. (interview transcript, p. 7).

Helina also expressed a desire to learn more about online platforms such as Google Classroom and Zoom as well as other educational applications that are interactive (e.g., Edpuzzle, Pear Deck) aside from Google Jamboard that she had used in her lessons. Finally, she resolved to be clearer with her instruction by not only being more concise with her words but by speaking "their language" in order to be understood better by students.

\section{Natalie's Account}

Fears and Frustrations. Natalie's story began with her remembering how comfortable she had been with technology from a very young age. She recalled watching videos and playing video games. She regarded technology as a natural part of life, much like breathing, and enumerated 
many authentic ways to use technology for learning (e.g., exploring places through Google Maps; connecting with experts). However, despite her comfort with technology, Natalie admitted she felt intimidated by the idea of virtual tutoring. One of her concerns was her ability to maintain her student's interest and attention, especially with the belief that even adults struggle to stay focused in virtual learning environments. Realizing that her 1st grade student, Adi, would have been in school all day, she wondered if she could keep him engaged. An added layer to her anxious feelings was her nervousness about meeting a new student and entering into that getting-to-know stage.

Her affect for the virtual tutoring then shifted to moments of frustration. She recounted an instance when her student did not respond the way she anticipated, and it made her step back and reflect about her teaching:

We built on [short vowels] and introduced long vowel sounds. And the end of the long vowel sound lesson, I remember feeling really frustrated because he still wasn't getting it. And I was like, "Okay. What did we do wrong? What are we missing here? (interview transcript, p. 9).

Creating and Adjusting Instruction to Foster Engagement. Natalie described the different literacy activities she and her partner facilitated with Adi. These included identifying elements of a story, sorting words with short and long vowel sounds, and decoding words with the 'qu' pattern. For instruction, she mentioned using "YouTube videos because Adi responded well to those, and tried to get him to physically engage by asking him to draw illustrations of the book and stories read ... [Adi] loves to draw so this was really engaging for him" (final paper, p. 3).

As Natalie continued describing her tutoring experiences with Adi, we noticed that Natalie made several instructional modifications geared towards increasing engagement and promoting a positive virtual learning environment for Adi. Here is one example where she decided to instantaneously modify her lesson:

[...] he got on the conference (call) and was just not in a good mood. He was upset. I was like, "Do you want to talk about it?" And he's just, "No." So I was like, "Alright. I will read the story to you. I just want you to listen." And then--I quickly decided to do a read aloud version instead of having him read it. And it's a silly book and I would pause every so often and be like, "Oh do you--" I would just have him respond to whatever was on the page. And by the end of it, he was much more excited" (interview transcript, p. 5).

Another moment which had a significant impact on her was a moment when she made another breakthrough with Adi. She explained that it was important for her to see her student from where he was coming from and continue to get to know him on a deeper level. She sensed that he was having a rough day and she could tell he was frustrated. She invited Adi "Do you want to take a break and meet our cats?" (interview transcript, p. 13) to which we imagined that he agreed with enthusiasm. According to her, that interaction really developed a more rounded 
sense of knowing Adi. She had noted that after Adi met her and her partner's pets, they were able to continue the lesson more smoothly (final paper, p. 4).

Respecting the Family's Privacy. Natalie's experience interacting with Adi's family is a unique story to tell. During her tutoring sessions, she thought of the times when she sensed that Adi's parents seemed shy to interact with her. She said she knew that Adi's parents would be around to set up the virtual meeting for him, blur his background, and occasionally reminded Adi to pay attention to us, but they never appeared on camera. She thought that blurring Adi's background may have been due to their desire to maintain their privacy. Having shared her personal impression of Adi's family, we understood the context for Natalie's reaction to the family conference when neither parent came to attend:

[...] That's why I was a little disappointed because I didn't get that experience to interact with them... but it's still an experience that I can expect to have in my career as a teacher. So I'm not super disappointed. And I at least appreciated that he responded with telling us why he didn't come. (interview transcript, $p$, 15).

According to her, she and her partner waited for thirty minutes until they just decided to email the parents and inquire. They eventually received a response that the father did not make it to the conference because he was in a meeting at that time.

Realizations from Virtual Tutoring. Natalie defined her success in virtual tutoring in terms of the times when Adi understood the content (e.g., when Adi grasped the concept of short and long vowels). When further probed for how else she may have felt successful in virtual tutoring, she added her thoughts on having a positive relationship with Adi:

I felt successful in developing a relationship or rapport with him. Like his drawings were always really fun because if he were to draw something and like bring it to us the next day or the next session, he'd be like, "Oh look what I did, look what I did." And that was really encouraging, I guess. So I enjoyed that aspect of it... with the one on one kind of sessions, it really is more rewarding because you really get into what they're doing and they get into it too. (interview transcript, p. 9).

Additionally, she recounted the different ways she tried to get to know Adi--by asking him about his day instead of immediately starting the lesson and inviting him to show his favorite book. She said that it was during those kinds of conversations that led Adi to share his interest in cats and even showed her his stuffed animal cat. She explained that the incident stayed with her which prompted her to later share her own pets with him.

As we approached the end of our conversation, Natalie summarized the meaning of her virtual tutoring experience. She realized that a level of anxiety always came from not knowing how Adi was going to respond to her lessons. She worried that the lessons were either too advanced or not engaging enough. To her surprise and relief, Adi had a positive response almost every time. She revealed there were also times she felt that Adi did not want to be at tutoring. 
And while those times were harder to navigate, she said she understood the position of the student and left us with this advice:

I honestly think one of the most important elements for me in beginning this whole experience was really having that interest inventory to build on. And I think one of the biggest considerations you have to have when you're doing this kind of instruction is you really have to focus on their interests because otherwise it's almost impossible to get them engaged in this format especially at his age because he's limited in his capabilities when it comes to technology. (interview transcript, p. 16).

\section{James' Account}

Teacher-Centered Moving Towards Student-Centered. James recalled nervousness and uncertainty when preparing for virtual tutoring. He felt "I didn't have any idea how this was going to go ... it was a little nerve wracking" (interview transcript, p. 2). He described the literacy skills he and his partner facilitated with their third-grade student, Mojib. They focused on informational texts and developing paper-based annotation skills. They used Microsoft Word and screen-shared their modeling of annotation by highlighting. They used the website Ducksters.com to access historical figures and quizzes. Each week Mojib selected an historical figure to read about and practiced his annotation skills. Mojib would then complete the online quiz with James by verbally answering each question.

This lesson structure was designed to accommodate the lack of time James had to plan for and develop lessons:

We were kind of so busy with other classes. [My partner and I] really liked what we did so we would add that into the lesson plan, but not completely add a new element. Like, it was very similar: ask [Mojib] some questions, read him some stuff about new people, he learns how to annotate, he's learning how to comprehend, and he answers a quiz, or he writes. It's kind of it. (interview transcript, p. 8-9).

While James' lessons were highly structured and fixed in curricular content (Author 2 fieldnotes), there were burgeoning aspects of student-centered learning. James did not rely on the Literacy Interest Inventory, instead building student interest into each lesson through an exit ticket. To prepare for the third week of tutoring, James asked "what do you want to learn about?" Mojib wanted to learn about pandas so James built a literacy lesson on the topic 'pandas'. This process became part of the routine, as James explained: 
We would be, 'What did you think of the lesson, or what did you think of the material you just learned?' and 'What do you want to learn?' And that really was it. So, we asked him, I think the first couple lessons, after each lesson, like what I just said. And he would say one thing he wanted to learn and then we would make that lesson half of what he said and then we would repeat that after the next lesson. And we would just kind of continue. (interview transcript, p. 7).

Handling Challenges. James' story continued by delving into the challenges he faced in virtual tutoring. For instance, he offered caveats as he described Mojib's intellectual abilities, "I'm not a teacher yet, but he seemed like he was grades ahead of where he should be" (interview transcript, p. 6) or "And it's like I'm not really one to tell him what to work on. I don't have my degree yet" (interview transcript, p. 15). This may have impacted his actions when addressing challenges in lessons. For example, Mojib routinely turned the microphone off during the lesson. This persisted in each lesson despite James requesting the microphone stay on and left James frustrated:

I didn't want to be rude. I didn't know how to talk, we didn't want to be like, "You have to turn your mic on or we're going to email your dad." I mean, I couldn't say that. I wish I did. I don't know. But we would be, 'Hey [Mojib] can you please turn on your mic?' And he would just look at the camera. And we were asking him for the third time and typing it in the chat. Then he would, and then he would turn it off five minutes later. So that was just awkward, like can I be a little more strict with [Mojib]? I don't know how I should. I want to be professional, like I don't really know. (interview transcript, p. 16)

James also described communication frustrations, such as a time Mojib read a text aloud with the microphone off. James asked, "Do we ask him to read it again?" Or times when James wanted to check-in with Mojib's annotation progress but Mojib could not screen-share, "[he] was communicating with us saying, 'I can't'-- just wouldn't respond." In an effort to problemsolve, James requested Mojib's father to email the work to him and his partner; however, the email did not come, and James said he was unsure if and how Mojib annotated the text. He lamented a desire to provide more direction but did not know the appropriate avenue to ask, "we want you to be here. We want you to be at your house. We need reliable Internet. We need you to be paying attention. We need you to always have your mic on."

Experience and "What Could Be." We acknowledge that James' experience was the most challenging virtual teaching scenario to date in our program. In the final lesson, James entered the web-conferencing space to discover Mojib traveling in his family's car. James recalled, "I just started shaking my head thinking this isn't going to work. Not good." Despite the strangeness of the learning environment, James began the lesson. He recalled:

We couldn't see him, but we were asking him if he could hear us and he wouldn't answer. Then, he put something in the chat 'yes.' So, then we would start the lesson, and then he dropped [again] like the first time. I think that happened 
three more times. Then the mic was on because we could hear his family--his brother or his dad calling or something. Then the camera was switching to be his dad or his mom. And I was just thinking this is awkward and not going well" (interview transcript, p. 18).

And yet, he persisted and the lesson was completed. James had emailed Mojib's father asking for the lesson materials and the father responded with all the work completed for that lesson (a post-assessment of reading comprehension).

James identified what he wished he had approached differently in virtual tutoring: lesson plans and technology. With respect to lessons, he expressed a desire to diversify the structure and focus of lessons:

I didn't feel we changed enough. When I look back on it, we were so busy with other classes. I was-- we really liked what we did so we would add that into the lesson plan, but not completely add a new element. It was very similar, now that I think about it: ask him some questions, read him some stuff about new people, he learns how to annotate, he's learning how to comprehend, and he answers a quiz, or he writes. That's kind of it. And I think we should have probably changed that. I think we could have added a new element or a new website or a new tool to try to broaden the comprehension stuff using other stuff instead of just using similar material. (interview transcript, p. 8-9).

Had time not been an issue, James felt he would have learned how to diversify his lesson plans and "learn how a teacher builds a specific [skill] they're working on without just using the same tactic" (interview transcript, p. 10). In a similar vein, James wished he had had the time to thoroughly explore digital resources for virtual teaching. A course assignment had required PSTs to develop a text set for virtual tutoring. James had found a number of texts but he did not feel he took the time to learn how to use them to their full potential. He told us "if I had time, I would have actually wanted to go through and use those tools that I had found" and learn "more about virtual." Especially as it related to building a rapport with his student:

I know virtual [learning] would be hard, talking with two random dudes. I have never seen this person. But just really trying to make the student feel more comfortable. To open up and [say], 'This is what I really want to learn' or 'I didn't like this lesson plan'. (interview transcript, p. 10).

While the interview seemed to emphasize the challenges and annoyances James experienced, he did not view the experience negatively. He emphasized that virtual tutoring was:

[...] was a good experience. I know we talked a lot about negatives, but it really was good. I learned a lot, and I know [partner] learned a lot ... it was a good experience. I learned a lot from it. It was worth it. Especially since, who knows how long we will be doing virtual. I hope not long, but it was great to have an 
opportunity to see what it was like, even if it was just with one student" (interview transcript, p. 20).

\section{DISCUSSION}

To situate our discussion, we first characterized PSTs' experiences within virtual tutoring. Then, we moved into discussing the ways PSTs work towards socially just literacy teaching within this virtual tutoring context.

\section{PSTs' Literacy Teaching Experiences in Virtual Tutoring}

Our participants' stories illustrated literacy lessons facilitated in different ways. After they conducted pre-assessments to determine their students' instructional needs, their lesson plan foci diverged into the areas of teaching phonics (e.g., vowel digraphs, short and long vowels), elements of a story, predicting, inferring, and text annotation. We found this reaffirming of our teaching philosophy that students need skilled teachers who can identify students' strengths and needs and differentiate instruction accordingly (Education Endowment Foundation, 2021; Kunz \& Lapp, 2020) and even more so in virtual spaces given the inequitable access to education (Doyle, 2020; Jæger \& Blaabæk, 2020). To facilitate lessons, they utilized a wide variety of teaching activities: word sorts, games, read alouds, IRE (initiate, response, evaluate), and quizzes. Additionally, they combined print-based and multimodal resources, such as hard copies of texts, eBooks, Google Jamboard, and YouTube videos, either "screenshared" or emailed to the family. Majority of their instruction relied on oral explanation or oral discussion. While we promoted a pedagogy of multiliteracies in the course (Cope \& Kalantzis, 2000, 2009) we also learned that PSTs are exploring print-based and digital texts while using tools and resources that they had access to at that time (Gee, 2015; Walsh, 2008). Like us, they too were learning and building their knowledge of teaching literacy virtually (Kunz \& Lapp, 2020).

Across all participants, the PSTs also described varying levels of anxiety and nervousness upon first hearing of the virtual tutoring field experience as well as feeling overwhelmed by the amount of work involved in teaching. These findings show that feelings of apprehension, anxiety, and nervousness that PSTs face during their in-person field experiences (Yuan \& Lee, 2016; Wilkens et al., 2014) are also experienced in virtual contexts. Regardless of their comfort levels using technology (e.g., Kerry and Natalie), they all felt anxious not knowing what to expect. For James, other aspects remained uncertain throughout the field experience (e.g., handling challenges) and even extended into his own identity as a teacher. Zimmerman et al. (2019) caused us to reflect on how much of our work as teacher educators involves addressing the affective dimension that also comprise PSTs' field experiences.

\section{Working Towards Socially Just Literacy Teaching}

In our inquiry, Nieto (2013) helped us to think that PSTs become socially just literacy teachers through a lifelong process of transformative practice. We discuss the different renditions of this 
process below by returning to the four components of Cochran-Smith's (2010) theory of practice for socially just teaching.

\section{Knowledge}

Our participants' stories suggest PSTs' valuing for traditional knowledge (e.g., phonics instruction). However, after recognizing their students' needs, they were able to reframe their thinking towards more socially just teaching through Fraser's (2003) notion of recognition and redistribution (i.e., rethinking how and what kinds of knowledge should be taught). For instance, Kerry questioned its universality (e.g., teaching all students about Thanksgiving). Helina solicited her student's input on future lessons while Natalie reflected with the question, "What are we missing here?" James also privileged traditional knowledge (e.g., text annotation) but later realized he should have changed the lesson.

\section{Interpretive Frameworks}

Having been assigned to teach students of color, we observed all our participants showed a deep respect for each of their students despite their racial and cultural differences. This respect was shown based on the way they interacted with them, which we believe was also influenced by their stance towards teaching and their own understanding of themselves as a novice teacher. Kerry gravitated towards an inquiry stance and a 'centering on the student' rather than maintaining her agenda. Helina demonstrated an asset-based perspective by recognizing that her student has something to offer. Natalie assumed a relational stance, with her strong focus on engagement and establishing rapport, while James approached virtual tutoring from an experiential stance, remaining to be open to whatever came his way and persisting through multiple challenges. We see this practice supported by what Smith et al. (2020) offered, that socially just literacy teaching in virtual spaces means meeting the student for who they are and wherever they are, while also exercising empathy in light of the current crisis (Baba, 2020). And though their experiences were marked by highs and lows, they were reflective and identified opportunities for growth during the interviews. This highlights the importance of including critical reflection when thinking about PST curricula (Aronson et al., 2020).

\section{Literacy Strategies, Methods, and Skills}

PSTs implemented literacy lessons while using different activities mediated by their students' interests in and response to the activities. We see these actions resembling Fraser's (2003) idea of recognition (i.e., making students' personal backgrounds visible in the curriculum), while also underscoring PSTs' varying understandings of what it means to use what they know about their students to design instruction (Villegas \& Lucas, 2002) and the asset-based perspectives undergirding their mindset (Souto-Manning, Llerena, Martell, Maguire, \& Arce-Boardman, 2018).

\section{Advocacy and Activism}

We did not see accounts of advocacy or activism embodied by our participants except for Kerry who explicitly stated that she viewed the family as a part of the classroom. In a sense, she knew and advocated for the family's role in building community. The limited opportunities to interact 
with families and the short duration of tutoring may be partly the reason but this finding reminds us to provide PSTs more experiences working with families (Evans, 2013; Graue \& Brown, 2003).

\section{CONCLUSION}

We learned through this inquiry that framing literacy instruction in virtual spaces from the lens of socially just teaching is a complex process (Lee, 2011) characterized by personal, contextual, and relational aspects. We highlighted the personal aspects of this process, given the personal backgrounds and past literacy teaching experiences our PSTs bring into virtual teaching. The process is also contextualized as PSTs work through different circumstances (e.g., affordances or challenges with technology), different students who also bring in their unique personal and family backgrounds and strengths as literacy learners. Finally, the process is also relational as PSTs try to work along with their peers (co-tutors) in planning and facilitating lessons, establishing good rapport with their students and their families, while also trying to meet course expectations. Though our study is limited in scope, we hope the stories outlined here provide a meaningful situated interpretation to Nieto's (2013) words, that socially just literacy teaching in virtual spaces is a lifelong process of transformative practice for PSTs.

\section{REFERENCES}

Aronson, B., Banda, R., Johnson, A., Kelly, M., Radina, R., Reyes, G., Sander, S., \& Wronowski, M. (2020). The social justice teaching collaborative: A collective turn towards critical teacher education. Journal of Curriculum Studies Research, 2(2), 21-39. https://curriculumstudies.org/index.php/CS

Au, K. H., \& Jordan, C. (1981). Teaching reading to Hawaiian children: Finding a culturally appropriate solution. In H. T. Trueba, G. P. Guthrie \& K. H. Au (Eds.), Culture and the bilingual classroom: Studies in classroom ethnography (pp. 139-152). Newbury House.

Baba, M. M. (2020). Navigating COVID-19 with emotional intelligence. International Journal of Social Psychiatry, 66(8), 810-820.

Baldwin, S. C., Buchanan, A. M., \& Rudisill, M. E. (2007). What teacher candidates learned about diversity, social justice, and themselves from service-learning experiences. Journal of Teacher Education, 58(4), 315-327.

Basilaia, G., \& Kvavadze, D. (2020). Transition to online education in schools during a SARSCoV-2 Coronavirus (COVID-19) pandemic in Georgia. Pedagogical Research, 5(4), 1-9. https://doi.org/10.29333/pr/7937

Brown, K. D. (2013). Trouble on my mind: Toward a framework of humanizing critical sociocultural knowledge for teaching and teacher education. Race Ethnicity and Education, 16(3), 316-338. https://doi.org/10.1080/13613324.2012.725039

Chase, S. E. (2008). Narrative inquiry: Multiple lenses, approaches, voices. In N. K. Denzin \& Y. S. Lincoln (Eds.), Collecting and interpreting qualitative materials (pp. 57-94). SAGE Publications, Inc. 
Clandinin, D. J.\& Connelly, F. M. (2000). Narrative inquiry: Experience and story in qualitative research. Jossey-Bass.

Cochran-Smith M. (2010) Toward a theory of teacher education for social justice. In A. Hargreaves, A. Lieberman, M. Fullan, \& D. Hopkin (Eds.), Second international handbook of educational change (2nd ed., Vol. 3, pp. 445-467). Springer Publishing. https://doi.org/10.1007/978-90-481-2660-6_27

Compton, L., Davis, N., \& Meek, B. (2008). Virtual field experience-Preparing future teachers for e-learning in secondary schools. Researchgate.net, 1- 11. https://www.researchgate.net/profile/LilyCompton/publication/228763547_Virtual_field_experiencePreparing_future_teachers_for_elearning_in_secondary_schools/links/02e7e5398f6cdc4423000000/Virtual-fieldexperience-Preparing-future-teachers-for-e-learning-in-secondary-schools.pdf

Cope, B., \& Kalantzis, M. (2000). Multiliteracies: Literacy learning and the design of social futures. Routledge.

Cope, B., \& Kalantzis, M. (2009). "Multiliteracies": New literacies, new learning. Pedagogies: An International Journal, 4(3), 164-195. http://dx.doi.org/10.1080/15544800903076044

Dahl, H. M., Stoltz, P., \& Willig, R. (2004). Recognition, redistribution and representation in capitalist global society: An interview with Nancy Fraser. Acta Sociologica, 47(4), 374382.

Doyle, O. (2020). COVID-19: Exacerbating educational inequalities? Working Paper. Public Policy. IE.

Education Endowment Foundation. (2020). Best evidence on supporting students to learn remotely. Education Endowment Foundation. https://educationendowmentfoundation.org.uk/covid-19-resources/best-evidence-onsupporting-students-to-learn-remotely/

Evans, M. P. (2013). Educating preservice teachers for family, school, and community engagement. Teaching Education, 24(2), 123-133.

Fereday, J., \& Muir-Cochrane, E. (2006). Demonstrating rigor using thematic analysis: A hybrid approach of inductive and deductive coding and theme development. International Journal of Qualitative Methods, 5(1), 80-92.

Fraser, N. (2003). Social justice in an age of identity politics: Redistribution, recognition and participation. In N. Fraser \& A. Honneth (Eds.), Redistribution or recognition: A politicalphilosophical exchange (pp. 7-109). Verso.

Gay, G. (2002). Preparing for culturally responsive teaching. Journal of Teacher Education, 53(2), 106-116.

Gee, J. P. (2015). A situated sociocultural approach to literacy and technology. In E. Baker (Ed.), The new literacies: Multiple perspectives on research and practice (pp. 165-193). Guilford Press. 
Graue, E., \& Brown, C. P. (2003). Preservice teachers' notions of families and schooling. Teaching and Teacher Education, 19(7), 719-735.

Harambam, J., Aupers, S. \& Houtman, D. (2013). The contentious gap: From digital divide to cultural beliefs about online interactions. Information, Communication \& Society, 16(7), 1093-1114.

https://www.tandfonline.com/doi/abs/10.1080/1369118X.2012.687006https://doi.org /10.1080/1369118X.2012.687006

Isidro, E. (2019). Transactions in doing design-based research for designing curriculum: a selfstudy. Reflective Practice, 20(1), 85-96.

Kennedy, K., \& Archambault, L. (2012). Offering preservice teachers field experiences in K-12 online learning: A national survey of teacher education programs. Journal of Teacher Education, 63(3), 185-200. https://doi.org/10.1177/0022487111433651

Kunz, K., \& Lapp, D. (2020). Focus on Comprehension: Supporting learners in becoming more fluent comprehenders in a virtual classroom. Literacy Today, 38(2), 12-14. http://web.a.ebscohost.com.libproxy.library.wmich.edu/ehost/pdfviewer/pdfviewer?vi $\mathrm{d}=1$ \&sid=ee53372a-9770-4367-a3d8-3fb7e2b5a63d\%40sdc-v-sessmgr02

Ladson-Billings, G. (1995). Toward a theory of culturally relevant pedagogy. American Educational Research Journal, 32(3), 465-491.

Lee, Y. A. (2011). What does teaching for social justice mean to teacher candidates? Professional Educator, 35(2), 1-20. https://files.eric.ed.gov/fulltext/EJ988204.pdf

Moore-Hayes, C. (2011). Technology integration preparedness and its influence on teacherefficacy. Canadian Journal of Learning and Technology, 37(3), 1-15.

Nieto, S. (2013). Finding joy in teaching students of diverse backgrounds: Culturally responsive and socially just practices in U.S. classrooms. Heinemann.

Paris, D., \& Winn, M. T. (2013). Humanizing research: Decolonizing qualitative inquiry with youth and communities. SAGE Publications.

Rogers, R., Kramer, M. A., Mosley, M., Fuller, C., Light, R., Nehart, M., Jones, R., Beaman-Jones, S., DePasquale, S. B. and Thomas, P. (2005). Professional development as social transformation: The literacy for social justice teacher research group. Language Arts, 82(5), 347-358.

Smith, S., West, J., \& Buchholz, B. (2020). New space, new rules? Learning how to be together online. Literacy Today, 38(1), 38-39.

Souto-Manning, M., Llerena, C. L., Martell, J., Maguire, A. S., and Arce-Boardman, A. (2018). No more culturally irrelevant teaching. Heinemann.

Toquero, C. M. (2020). Challenges and opportunities for higher education amid the COVID-19 Pandemic: The Philippine context. Pedagogical Research, 5(4), 1-5. https://doi.org/10.29333/pr/7947

Trumble, J. (2016, March). Internships and TPACK: The impact of student teaching on novice teachers' self-perceived TPACK. In G. Chamblee \& L. Langub (Eds.), Proceedings of 
society for information technology \& teacher education international conference (pp. 3086-3090). Association for the Advancement of Computing in Education.

Van Allsburg, C. (1981). Jumanji. Houghton Mifflin Harcourt.

Villegas, A. M., \& Lucas, T. (2002). Preparing culturally responsive teachers: Rethinking the curriculum. Journal of Teacher Education, 53(1), 20-32. https://doi.org/10.1177/0022487102053001003

Walsh, M. (2017). Multiliteracies, multimodality, new literacies and... what do these mean for literacy education?!n M. Milton \& C. Forlin (Eds.), Inclusive principles and practices in literacy education, (pp. 19-33). https://doi.org/10.1108/S1479-363620170000011002

Waters, S., \& Russell III, W. (2016). Virtually ready? Pre-service teachers' perceptions of a virtual internship experience. Research in Social Sciences and Technology, 1(1), 1-23. https://www.researchgate.net/publication/306254943_Virtually_Ready_Preservice_teachers_perceptions_of_a_virtual_internship

Wilkens, C., Eckdahl, K., Morone, M., Cook, V., Giblin, T., \& Coon, J. (2014). Communication, community, and disconnection: Pre-service teachers in virtual school field experiences. Journal of Educational Technology Systems, 43(2), 143-157. http://dx.doi.org/10.2190/ET.43.2.c

Williamson, T. (2017). Listening to many voices: Enacting social justice literacy curriculum. Teaching and Teacher Education, 61, 104-114.

Woods, A. (2018). Socially just literacy education: What could reform look like in schools? In R. Henderson (Ed.) Teaching Literacies: Pedagogies and Diversity (2nd ed., pp. 211- 230). Oxford.

Yuan, R., \& Lee, I. (2016). 'I need to be strong and competent': A narrative inquiry of a studentteacher's emotions and identities in teaching practicum. Teachers and Teaching: Theory and Practice, 22(7), 819-841.

Zeichner, K. (2011). Teacher education for social justice. In D. M. R. Hawkins (Ed.), Social justice language teacher education (pp. 7-22). Multilingual Matters.

Zimmerman, A., Greenlees, L., Isidro, E., and Sneed, S. (2019). Knowing teaching poetically. Learning Landscapes, 12(1), 303-315. https://doi.org/10.36510/learnland.v12i1.995 